UDC 693.546

\title{
DISCRETE-CONTINUAL MODEL TO ANALYZE AND OPTIMIZE (MINIMIZE) DYNAMIC LOADS IN ELASTIC ELEMENTS/ROPES FOR LIFTING EQUIPMENT
}

\author{
Yu. V. Chovnyuk, I. M. Sivak
}

National University of Life and Environmental Sciences of Ukraine. Ukraine

Speciality of article: 133 - industry engineering.

Corresponding authors: ychovnyuk@ukr.net.

Article history: Received-October 2019, Accepted-January 2020.

Bibl. 11, fig. 1, tabl. 3.

\begin{abstract}
The discrete-continuum model for analysis and its optimization (minimization) of dynamic loads in elastic elements (ropes) of load-lifting machines is substantiated.

The influence of distributed and lumped parameters of elastic elements on the magnitude of the dynamic loads in them on the sections of transition processes (descent, inhibition, reversal of motion) is determined.

The proposed criterion of the quality of movement of the lifting mechanism of the crane, which minimizes the coefficient of dynamism in the ropes, as well as the laws of the movement of cargo, in which these criteria of optimization of dynamic loads and elastic elements are implemented, are established.

For determination of dynamic loads in an elastic element, for example, in a rope a two-mass model of a discrete type (with lumped parameters) is used, with the help of possible reactions in the motion of the drive mechanism with the drum at the descent, the reaction of motion with constant acceleration is used which minimizes the value of the driving moment drive, linear motion reaction acceleration, which minimizes the dynamic component of the drive power, reaction of motion with change of acceleration of the third order, the reaction of motion with the change of acceleration in its curve of the fifth order.
\end{abstract}

Key words: continuity, model, analysis, optimization, minimization, dynamics, loads, elastic elements, ropes, hoisting machines, cranes.

\section{Introduction}

The performance and reliability of hoisting machines, precision and performance of different types of jobs: unloading, loading, transport and other - essentially depends on the dynamic loads in elastic elements of flexible working, drive and hardware. The values of these loads depends on the area of movement of lifting machinery or its mechanism.

\section{Formulation of problem}

The most dynamic stresses occur in areas transients (downhill braking movement).

One way to reduce these pressures on the drive elements are resilient cranes lifting mechanisms is necessary choices for their movements in areas transients.

\section{Analysis of recent research results}

In [1] showed that during braking during downhill dynamic load factor in elastic elements of crane mechanisms reaches 2.5 or more. In [1-4] the effect of various reactions to dynamic traffic load in elastic elements of lifting equipment for example lifting mechanism. To determine the dynamic loads in the elastic element, for example, used a rope dvomasova discrete model type (with lumped parameters) diagram is presented below in Fig. 1.

At the same time as possible reactions in motion with a drum drive mechanism at the site of descent used the following $4[3,4]$ : 1) reaction motion with constant acceleration, which minimizes the value of the driving time of the drive, 2) reaction movement with linear acceleration change, which minimizes dynamic component power drive, 3) reaction to the change of motion acceleration third order, 4) reaction to the change of motion acceleration curve in his fifth order. It is the last two reactions give a smooth change of motion acceleration curved drum mechanism that would reduce the fluctuations of dynamic loads in the spring elements, but does not minimize them as a dynamic factor.

In [4] The effect of movement in response to the change and maximum values of dynamic loads in the rope when lifting load at startup, but does not include properties rope spread as elastic element lifting mechanism of the crane.

The impact of distributed properties of cables, according to the authors of this study can be defined using the approaches set out in [5-21]. 


\section{Purpose of research}

The purpose of the work is justification discretecontinuum model of lifting mechanism of a crane, which allows for distributed properties of the spring element (rope) and allows the absence to the selected quality criteria of the system to minimize the dynamic loads on the rope, to determine optimal in this sense, the laws of motion of the cargo and the drive mechanism of the drum and to identify their oscillation frequency rope that define its resonances, subject to the availability of goods enshrined in it.

\section{Results of research}

The dynamic model of valve lift mechanism as a system with lumped parameters and its analysis.

The diagram of the dynamic model (discrete type) lifting mechanism (Fig. 1) made the following notation [4]: $\mathrm{m}, \mathrm{m} 1$-built lifting channel to the masses under load and drive mechanism of the drum, $\mathrm{x}, \mathrm{x} 1$ - generalized coordinates of mass $\mathrm{m}, \mathrm{m} 1,(\mathrm{~F} 2, \mathrm{~F} 1$ - cargo weight $(\mathrm{F} 2=\mathrm{m} 1 \cdot \mathrm{g}, \mathrm{g}-$ acceleration due to gravity) and the driving force of the drive construction to cargo rope, $\mathrm{C}$ - tightening rope.
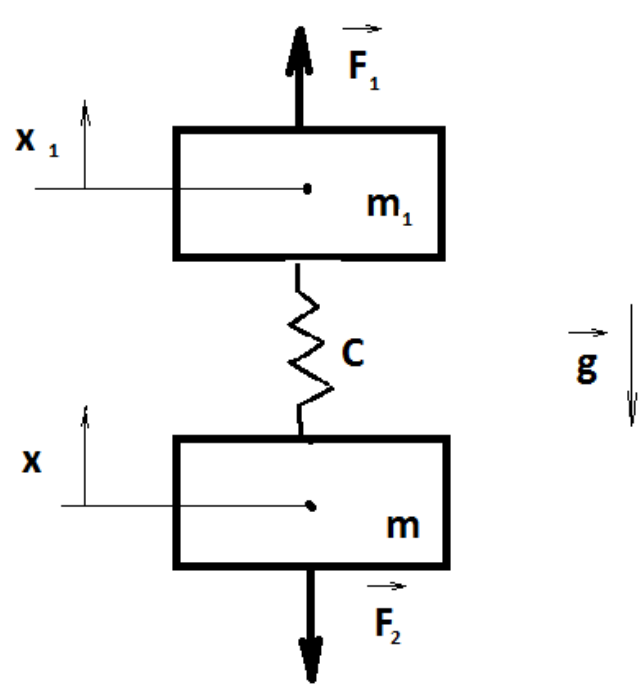

Fig. 1. The dynamic model of the crane lifting mechanism as systems with lumped parameters (discrete model type).

In the first approximation $\mathrm{P}=\mathrm{E} \mathrm{S} / \mathrm{e}$, where e modulus material tightrope, $\mathrm{S}$-area of its cross section, $1-$ rope length).

The model equations of motion lifting mechanism have the form (4):

$$
\left\{\begin{array}{c}
m 1 \cdot x=F 1-\ddot{C} \cdot(x 1-x) \\
m \cdot \ddot{x}=(x 1-x)-F 2
\end{array}\right.
$$

Which easily through simple changes to reduce to a single equation for $\mathrm{X}(\mathrm{E})$ fourth order.

Given the fact that the driving force of the drive drum is determined: $\mathrm{F} 1=\mathrm{F} 2+(\mathrm{m}+\mathrm{m} 1) \cdot \mathrm{a}(\mathrm{t})=\mathrm{mg}+(\mathrm{m}$ $+\mathrm{m} 1) \cdot \mathrm{a}(\mathrm{t})$, going from (1) have:

$$
\left.X^{(I V)}+k^{2} \cdot x \stackrel{\ddot{=}}{=} k^{2} \cdot a(t) \text { where } k=\sqrt{\left(\frac{1}{m}+\frac{1}{m 1}\right.}\right) \cdot C .
$$

C - frequency natural vibrations of the discrete dynamic model of lifting mechanism, $\mathrm{t}-$ time, $\mathrm{a}=\mathrm{a}(\mathrm{t})-$ function acceleration of a motion mode drive mechanism with a drum, depending on the time $(\mathrm{t})$.

Solution (2) depends on the type of right that is determined by the mode of movement of the drive mechanism. Symbols Number mode 1, 2, 3, 4 above in the analysis of publications. For specific regime and $(\mathrm{t})$ has the following form:
a) First rezhym-

$$
a=v y / t n=\text { coust, }
$$
b) a second rezhym-

$$
a=\frac{2 v y}{t n} \cdot\left(1-\frac{t}{t n}\right)
$$

c) The third mode-

d) The fourth mode-

$$
a=12 \cdot \frac{v y \cdot t}{t n^{2}}\left(1-\frac{t}{t n}\right)^{2},
$$

$$
a=60 \cdot \frac{v y \cdot t^{2}}{t n^{3}} \cdot\left(1-\frac{t}{t n}\right)^{3} .
$$

Note that in the expressions (3)-(6) Vy - speed steady movement of cargo during its recovery, tn - length start (acceleration) of cargo.

Further that the point system was in the time of relative peace, that is:

$$
x \frac{(t)}{t=0}=0, x 1,1=0 \quad \frac{(t)}{t=0}=0 \dot{x} \frac{(t)}{t=0}=0 \dot{x} \frac{(t)}{t=0}
$$

Therefore, equation (2) should roz'yazuvaty under the following initial conditions:

$$
\begin{aligned}
X(t)=(A 1+A 2 \cdot t)+B 1 & \cdot \sin (k t)+B 2 \cdot \cos (k t)+ \\
& +x \text { part. }(T),
\end{aligned}
$$$$
x \frac{(t)}{t=0}=0, \dot{x} \frac{(t)}{t=0}=0 \ddot{x} \frac{(t)}{t=0}=-g, \dddot{x} \frac{(t)}{t=0}=0 .
$$

where the constants A1,2, V1,2 define the conditions (8) when a particular solution found (2) x part. (T). We will further deal with the movement of goods, which minimizes dynamic factor.

In the twisting element lifting mechanism, ie the rope, the section of its start when $\mathrm{tYe}[0, \mathrm{tn}]$ :

$$
\frac{1}{t n} \int_{0}^{t n}\{k \text { дин. }(t)\} \quad{ }^{2} d t \rightarrow \min
$$

From the second equation of (1) efforts to rope are defined as follows:

$$
F=C \cdot(x l-x)=m \ddot{x}+M g \text {. }
$$

Quality criteria of motion (10), based on (11) determines the performance of the following conditions necessary for its implementation (Euler-Poisson):

Then we have:

$$
x^{(I V)}=0 \text {. }
$$

$$
\left\{\begin{aligned}
x^{(I V)}+k^{2} \cdot x & =k^{\ddot{2}} \cdot a(t),<=>\ddot{x} a(t) . \\
x^{(I V)} & =n
\end{aligned}\right.
$$

So, to find $\mathrm{x}(\mathrm{G})$ for optimal cargo movement at the site start (in the sense of the criterion (10) should solve (13) with zero initial conditions:

$$
X \frac{(t)}{t=0}=0, \quad \dot{x} \frac{(t)}{t=0}=0 .
$$

According to relations (3)-(6) have.

For the first mode:

$$
X(t)=, \frac{v y}{t n} \cdot\left(\frac{t^{2}}{2}\right) .
$$

For the second mode:

$$
X(t)=, \frac{2 v y}{t n} \cdot\left\{\frac{t^{2}}{2}-\frac{t^{3}}{6 t n}\right\} .
$$

For the third mode:

$$
X(t)=\frac{12 v y}{t n} \cdot\left\{\frac{t^{3}}{6 t n}-\frac{t^{4}}{6 t^{2} n}+\frac{t^{5}}{20 t^{3} n}\right\} .
$$


For the fourth mode:

$$
X(t)=\frac{60 v y}{t n} \cdot\left\{\frac{t^{4}}{12 t^{2} n}-\frac{3}{20} \cdot \frac{t^{5}}{t^{3} n}+\frac{t^{6}}{10 \cdot t^{4} n}-\frac{t^{7}}{42 \cdot t^{5} n}\right\} .
$$

For dynamic coefficient $\mathrm{k}$ din. $(+)$ (for each of the corners modes) are:

$$
k \operatorname{din} .(t)=+\frac{a(t)}{g}
$$

For the first mode of movement of the drum drive mechanism are:

$$
K \operatorname{din} .(T)=1+\frac{v y}{g \cdot t n}=\text { coust }>1 .
$$

For the second mode of motion of the drum drive mechanism are:

$K \operatorname{din} .(T)=1+\frac{2 v y}{g \cdot t n} \cdot\left(1-\frac{t}{t n}\right)=1+\frac{2 v y}{g \cdot t n}-\frac{2 v y \cdot t}{g t^{2} n} .(21)$

Maximum values of Dean $K(t)$ becomes the starting point, at $\mathrm{t}=0$ :

$$
\text { Dean } K(t) / \max =k d y n(t) / t_{=0}=1+\frac{2 v y}{g \cdot t n} .
$$

For the third motion mode drive mechanism with a drum ends

$$
\text { Kdyn. }(T)=1+\frac{12 v y}{g t n}\left(\frac{t}{t n}-2 \cdot \frac{t^{2}}{t^{2} n}+\frac{t^{3}}{t^{3} n}\right) .
$$

Maximum values of $\mathrm{k}$ dyn $(\mathrm{t})$ becomes $\mathrm{y}$ at time $\mathrm{t}=\operatorname{tn} / 3$.

$$
k d y n(t) / \max =k d y n(t) / t=\frac{t n}{3}=1+\frac{64 v y}{9 \cdot g \cdot t n} .
$$

For the fourth motion mode drive mechanism with a drum ends:

$$
k d y n(t)=1+. \frac{60 \cdot v y}{g t n} \cdot\left(\frac{t^{2}}{t^{2} n}\right) \cdot\left(1-\frac{t}{t n}\right) \quad 3 .
$$
$\mathrm{t}=: \frac{2}{5} \operatorname{tn}:$

Maximum values of $\mathrm{k}$ dyn $(\mathrm{t})$ becomes $\mathrm{y}$ at time

$$
\frac{k_{\text {дин }}(t)}{\max }=\frac{k_{\text {дин }}(\epsilon)}{t_{\frac{2}{5 t n}}}=1+\frac{1296 \cdot v y}{625 \cdot g \cdot t n} .
$$

The following Table 1 shows the $\min$ and $\max$ values:

$$
\begin{gathered}
k_{\text {дин }}^{(\mathrm{i})}(\Theta), \quad \text { and }=(1.4) \\
\text { for } g=9,81 \mathrm{~m} / v_{y}=\frac{0,5 \mathrm{~m}}{c}, t_{n}=2,0 \mathrm{c}, c^{2}
\end{gathered}
$$

Table 1. The value of $\min$ and $\max k_{\text {дин }}{ }^{(i)}(t), \mathrm{i}=$ $(1,4)$.

\begin{tabular}{|c|c|c|}
\hline and & $k_{\text {дин }}{ }^{(\mathrm{i})} / \min$ & $k_{\text {дин }}{ }^{(\mathrm{i})} / \max$ \\
\hline 1 & 1,025 & 1,025 \\
\hline 2 & 1,000 & 1,025 \\
\hline 3 & 1,000 & 1,181 \\
\hline 4 & 1,000 & 1,053 \\
\hline
\end{tabular}

Note the following: 1) the minimum value for $\mathrm{i}=(2,4)$ becomes time $\mathrm{t}=\mathrm{tn}$, ie at the end of the period of start-up, 2) for $\mathrm{i}=(1,4)$ is not the case optimal cargo movement (oscillating) character (in contrast to the results obtained у. $\left.k_{\text {дин }}(\mathrm{i})(€) k_{\text {дин }}^{(\mathrm{i})}(t)[4\rceil\right)$.

Incidentally, at time $\mathrm{t}=0$ (early start):

$$
k_{\text {дин }}(t) \text { for } i=(3,4) k_{\text {дин }}(\epsilon)=1 \text {. }
$$

Thus, the motion mode drive mechanism of the drum, which ensure smooth movement and cargo, and also ideal value at the beginning $(t=0)$ and the late start $(t$ $=\mathrm{tn}$ ). This third and fourth modes (law a $(\mathrm{t})$ respectively).

Given (13), we have:

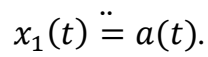

Since $x 1(t)$ are also zero-point conditions:

$$
X 1(t) /, t_{=0}=0 \frac{x 1(t)^{\circ}}{t_{=0}}=0
$$

Then the optimum law of motion $\mathrm{x} 1(\mathrm{t})$ coincide with corresponding to $\mathrm{x}(\mathrm{t})(15)(16)(17)(18)$.

The dynamic model of valve lift mechanism as a system of separated parameters and its frequency. Rope with no movement in the lifting mechanism.

Using the approach to work (6), determine the natural frequencies of the rod (model flexible rope) under the following boundary conditions:

When $\mathrm{z}=0$.

When $\mathrm{z}=1$, where 1-length of rope (at the time point lifting).

$$
m X(z)=E S=E \cdot S, \cdot p^{2} \cdots \frac{d X}{d z} \frac{d x}{d z} .
$$

where: $\mathrm{z}$ - coordinate pozdovzhenya (along the axis of the straight rope), $\mathrm{p}$ - rope natural frequency (at rest), $\mathrm{x}$ (z) - own modes of rope that performs longitudinal vibrations.

Custom modes of $\mathrm{x}(\mathrm{z})$ has the following form:

$$
X(z)=\cdot \sin \left(+\cdot \cos (), A_{1} \frac{p z}{v}\right) A_{2} \frac{p z}{v} .
$$

Where $\mathrm{v}$ - velocity of longitudinal waves in the rope,

$$
V=\sqrt{\frac{E}{p}}
$$

where: $\mathrm{p}$ - density material rope

With conditions at $\mathrm{z}=0$, we have $\mathrm{X}(\mathrm{z}) /=0$, so: $z_{z=0}$ $A_{2}=0$. The condition at $\mathrm{z}=1$ we have:

$$
m \cdot p^{2} \cdot\left(\frac{p l}{v}\right)=E \cdot \cos \cdot S \cdot \frac{p}{v}\left(\frac{p l}{v}\right) .
$$

Thus, the frequency equation taking into account the expression $=\mathrm{E} / \mathrm{p}$, is $v^{2}$ :

$$
\frac{p \cdot l}{v} \cdot \operatorname{tg}\left(\frac{p \cdot l}{v}\right)=\frac{p \cdot S \cdot l}{m} .
$$

So part of the equation (31) is a ratio of weight to the rope core end load $(\mathrm{m})$. The value of the first root of equation $(1 / \mathrm{v})$ depending on the ratio $=\mathrm{pS} \cdot 1 / \mathrm{m}$ following (see. Table 2) $p_{1} \alpha$ :

Table 2. Depending on $\left(\frac{p_{1 \cdot l}}{v}\right) \alpha=\frac{p \cdot S \cdot l}{m}$.

\begin{tabular}{|c|c|c|c|c|c|}
\hline$\alpha$ & 0.10 & 0.30 & 0.50 & 0.70 & 0.90 \\
\hline$p_{1} \cdot l / v$ & 0.32 & 0.52 & 0.65 & 0.75 & 0.82 \\
\hline$\alpha$ & 1.00 & 2.00 & 4.00 & 10,00 & \\
\hline$p_{1} \cdot l / v$ & 0.86 & 1.08 & 1.27 & 1.42 & \\
\hline
\end{tabular}

Calculate the natural frequency of oscillation system $\mathrm{p}_{1}$ for different values rope length 1 by the following values: $\mathrm{v}=\mathrm{Sm} / \mathrm{c}, \mathrm{E}=2 \cdot \mathrm{Pa}, \mathrm{S}=25 \cdot 10^{3} 10^{\mathrm{II}} 10^{-4} \mathrm{M}^{2}$.

$P=8 \cdot 10^{3} \frac{\mathrm{\kappa r}}{\mathrm{m}^{3}}$ (steel rope), $\mathrm{m} \mathrm{kg}$. Table 3 presents the value and importance of 1-frequency, which corresponds to a model system with lumped parameters and is defined, in this case, the expression $10^{3} p_{1} \Omega$ :

$$
\Omega=\sqrt{\frac{1}{m}+\frac{E S}{l}} .
$$

Table 3. Value $\mathrm{p}_{1}$ and depending on $1 \mathrm{y} \Omega$.

\begin{tabular}{|c|c|c|c|c|c|}
\hline$L, m$ & 5 & 15 & 25 & 35 & 45 \\
\hline$p_{1}, \mathrm{c}^{-1}$ & 320.0 & 173.0 & 130.0 & 107.1 & 91.1 \\
\hline$\Omega, \mathrm{c}^{-1}$ & 316.0 & 182.6 & 141.4 & 119.5 & 105.4 \\
\hline$L, m$ & 50 & 100 & 200 & 500 & \\
\hline$p_{1}, \mathrm{c}^{-1}$ & 86.0 & 54.0 & 31.8 & 14.2 & \\
\hline$\Omega, \mathrm{c}^{-1}$ & 100.0 & 70.7 & 50.0 & 31.6 & \\
\hline
\end{tabular}


The table shows that the value of $\Omega$ significantly exceed $\mathrm{p}_{1}$ especially for large rope length.

Natural frequencies rope for this case are determined by the following transcendental equation must solve using PC:

$$
\begin{gathered}
\left\{m m_{1} \cdot p^{4}-E^{2} \cdot S^{2} \cdot \frac{p^{2}}{v^{2}}\right\} \cdot \sin \left(\frac{p l}{v}\right)+\left\{E S \cdot \frac{p^{3}}{v} .\right. \\
\left(m m_{1}\right\} \cos \left(\frac{p l}{v}\right)=0 .
\end{gathered}
$$

The coefficient of dynamic rope lifting mechanism is determined by the formula given above for load securing points $(z=1)$ In the case of optimum start system set modes and traffic load over the drum (also the best in terms of quality criteria of the system at the site launch).

\section{Conclusions}

1. Reasonable physical-mechanical model of lifting mechanism of a crane at the site of its descent, dyskretnocontinual system parameters.

2. Modes of traffic load and drive mechanism with a drum that satisfy the quality criteria of the system that minimizes the coefficient of dynamic ropes on the site starting mechanism.

3. Obtained in the results can subsequently be used to analyze, refine, improve engineering methods for calculating mechanism lifting cranes on their site start considering discrete-continuum all the features of the latter, as well as to determine the characteristic natural vibration frequencies (long) ropes (with order to prevent their unwanted resonance vibrations) as the engine design (design of such systems and the real operation.

\section{References}

1.Garnec, V. M., Zajchenko, S. V., Chovnjuk, Ju. V., Shalenko, V. O. \& Prihodko Ja. S. (2015). Concrete the forming units. Constructive and functional to the scheme, principle of action, theory basis. Kyiv: Interservis.

2.Kuzin, V. N. (1981). Technology of roller formation of flat articles from fine-grained concrete. (Extended abstract of candidate thesis). Moscow construction institute, Moscow, USSR.

3.Rjushin, V. T. (1986). Research of working process and development of a method of calculation of cars of roller formation of concrete mixes. (Unpublished candidate thesis). Kyiv construction institute, Kyiv, USSR.

4.Lovejkin, V. S. \& Pochka, K. I. (2004). The dynamic analysis of roller forming installation with the rekuperativ drive. Dynamics, durability and reliability of farm vehicles. Works of the first International scientific and technical conference (DSR AM-I), 507-514. Ternopil.

5.Lovejkin, V. S. \& Pochka, K. I. (2007). Results of pilot studies of the modes of the movement of roller forming installation with the rekuperativ drive. The bulletin of the Kharkov national university of agriculture of P. Vasilenko, vol. 1, No. 59, 465-474.

6.Nazarenko, I. I., Smirnov, V. M., Pelevin, L. C., Fomin, A. V., Sviders'kij, A. T., Kostenjuk, O. O., Ruchins'kij, M. M., Djedov, O. P., Garkavenko, O. M. \&
Martinjuk, I. Ju. (2013). Bases of the theory of the movement of the digging and condensing cars of the construction industry with the optimum parameters operated in time. Kyiv: MP Lesja.

7.Zaichenko, S., Shalenko, V., Shevchuk, N. \& Vapnichna, V. (2017). Development of a geomechanic complex for geotechnical monitoring contour mine groove. Eastern-European Journal of Enterprise Technologies, vol. 3/9 (87), 19-25. DOI: 10.155/17294061.2017.102067.

8.Garnec, 'V. M., Chovnjuk, Ju. V., Zajchenko, S. V., Shalenko, V. O. \& Prihod'ko, Ja. S. (2014). Theory and practice of creation of units of formation of concrete. Mining, construction, road and meliorative machines, No. 83, 49-54.

9. Garnec,' V. M., Zajchenko, S. V., Prihod'ko, Ja. S. \& Shalenko, V. O. (2012). Development of scientific and practical recommendations about creation of units of formation of concrete. Mining, construction, road and meliorative machines, No. 79, 46-52.

10. Zajchenko, S. V., Shevchuk, S. P., Garnec, 'V. M. (2012). Power analysis of process of roller consolidation. Power: Economy, technology, ecology, No. 1 (30), 77-83.

11. Zajchenko, S. V., Shevchuk, S. P., Garnec, 'V. M. (2012). Three-dimensional modeling of process of roller consolidation of column fastening. Mining, construction, road and meliorative machines, No. 79, 40-45.

\section{Список літератури}

1.Гарнеиь В. М., Зайченко С. В., Човнюк Ю. В., Шаленко В. О., Приходько Я. С. Бетоноформувальні агрегати. Конструктивно-функціональні схеми, принцип дії, основи теорії. К.: Інтерсервіс, 2015. $238 \mathrm{c}$.

2.кузин B. H. Технология роликового формования плоских изделий из мелкозернистых бетонов: автореф. дис. ... канд. наук. Моск. инж.строит.ин-т. М., 1981.

3.Рюшин В. Т. Исследование рабочего процесса и разработка методики расчета машин роликового формования бетонных смесей: дис. ... канд. техн. наук. Киев. инж. -строит. ин-т. Киев, 1986.

4.Ловейкін B. C. Динамічний аналіз роликової формовочної установки 3 рекупераційним приводом. Динаміка, міинність $і$ надійність с.-г машин: Пр. I міжнар. наук.-техн.конф. (DSR AM-I). (Тернопіль, 4-7 жовт. 2004). Тернопіль, 2004. С. 507-514.

5.Ловейкін B. $\quad$ C., Почка $K . \quad$ I. Результати експериментальних досліджень режимів руху роликової формувальної установки з рекупераційним приводом. Вісн. Харк. нац. ун-ту сільськ. госп-ва ім. П. Василенка. 2007. Т 1. № 59. С. 465-474.

6.Назаренко I. I., Смірнов В. М., Пелевін Л. С., Фомін А. В., Свідерський А. Т., Костенюк О. О., Ручинський М. М., Дєдов О. П., Гаркавенко О. М., Мартинюк I. Ю. Основи теорії руху землерийних і ущільнювальних машин будіндустрії з керованими у часі оптимальними параметрами. К.: МП Леся, 2013. $188 \mathrm{c}$.

7.Zaichenko S., Shalenko V., Shevchuk N., Vapnichna $V$. Development of a geomechanic complex 
for geotechnical monitoring contour mine groove. Eastern-European J. Enterprise Technologies. 2017. Vol. 3/9 (87). P. 19-25. DOI: 10.155/1729-4061.2017.102067.

8.Гарнець В. М., Човнюк Ю. В., Зайченко С. В., Шаленко В. О., Приходько Я. С. Теорія і практика створення бетоноформувальних агрегатів (БФА). Гірн., буд., дор. та меліор. машини. 2014. Вип. 83. C. 49-54.

9. Гарнець В. М., Зайченко С. В., Приходько Я. С., Шаленко $B$. O. Розробка науково-практичних рекомендацій по створенню бетоноформуючих агрегатів (БФА). Гірн., буд., дор. та меліор машини. 2012. Вип. 79. С. 46-52.

10. Зайченко С. В., Шевчук С. П., Гарнейь В. М. Енергетичний аналіз процесу роликового ущільнення. Енергетика: Економіка, технологія, екологія. 2012. № 1 (30). С. 77-83.

11. Зайченко С. В., Шевчук С. П., Гарнецьь В. М. Тривимірне моделювання процесу роликового ущільнення стовбурного кріплення. Гірн., буд., дор. та меліор. машини. 2012. Вип. 79. С. 40-45.

\section{ДИСКРЕТНО-КОНТИНУАЛЬНІ МОДЕЛІ ПІД ЧАС АНАЛІЗУ ТА ОПТИМІЗАЦІЇ (МІНІМІЗАЦЇ̈) ДИНАМІЧНИХ НАВАНТАЖЕНЬ У ПРУЖНИХ ЕЛЕМЕНТАХ/КАНАТАХ ВАНТАЖОПІДЙОМНИХ МАШИН \\ Ю. В. Човнюк, I. М. Сівак}

Анотація. Обгрунтовано дискретно-континуальна модель для аналізу та його оптимізації (мінімізації) динамічних навантажень у пружних елементах (канатах) вантажопідіймальних машин.

3'ясовано вплив розподілених i зосереджених параметрів пружних елементів на величину динамічних навантажень у них на ділянках перехідних процесів (спуск, гальмування, реверсування руху). Запропонований критерій якості руху вантажопідйомного механізму крана, по якій мінімізується коефіцієнт динамічності в канатах, а також встановлено закони руху вантажу, при яких реалізується вказані критерії оптимізації динамічних навантажень і пружних елементах.

Для визначення динамічних навантажень в пружному елементі, наприклад, в канаті використана двомасових модель дискретного типу (з зосередженими параметрами), при цьому в якості можливих реакцій руху приводного механізму 3 барабаном на ділянці спуску використані реакції руху 3 постійним прискоренням, який мінімізує величину рушійного моменту привода, реакції руху лінійною зміною прискорення, мінімізує динамічну складову потужності приводу, реакції рухи зі зміною прискорення третього порядку, реакції рухи зі зміною прискорення в його кривої п'ятого порядку.

Ключові слова: дискретність, континуальність, модель, аналіз, оптимізація, мінімізація, динаміка, навантаження, пружні елементи, канати, вантажопідйомні машини, крани.
ДИСКРЕТНО-КОНТИНУАЛЬНЫЕ МОДЕЛИ

В АНАЛИЗЕ И ОПТИМИЗАЦИИ

(МИНИМИЗАЦИИ) ДИНАМИЧЕСКИХ НАГРУЗОК

В УПРУГИХ ЭЛЕМЕНТАХ / КАНАТАХ

ГРУЗОПОДЬЕМНЫХ МАШИН

Ю. В. Човнюк, И. Н. Сивак

Аннотация. Обоснована дискретноконтинуальная модель для анализа и его оптимизации (минимизации) динамических нагрузок в упругих элементах (канатах) грузоподъемных машин.

Выяснен влияние распределенных и сосредоточенных параметров упругих элементов на величину динамических нагрузок в них на участках переходных процессов (спуск, торможение, реверсирование движения).

Предложенный критерий качества движения грузоподъемного механизма крана, по которой минимизируется коэффициент динамичности в канатах, а также установлены законы движения груза, при которых реализуется указаны критерии оптимизации динамических нагрузок и упругих элементах.

Для определения динамических нагрузок в упругом элементе, например, в канате использована двухмассовых модель дискретного типа (с сосредоточенными параметрами), при этом в качестве возможных реакций в движения приводного механизма с барабаном на участке спуска использованы реакции движения с постоянным ускорением, который минимизирует величину движущего момента привода, реакции движения линейной изменением ускорения, минимизирует динамическую составляющую мощности привода, реакции движения с изменением ускорения третьего порядка, реакции движения с изменением ускорения в его кривой пятого порядка.

Ключевые слова: дискретность, континуальность, модель, анализ, оптимизация, минимизация, динамика, нагрузки, упругие элементы, канаты, грузоподъёмные машины, краны.

Yu. V. Chovnyuk ORCID 0000-0003-1889-0876.

I. M. Sivak ORCID 0000-0002-6297-587X. 
